\title{
The Effect of Thermo- Mechanical Treatment of Moso Bamboo (Phyllostachys Pubescens) on Its Sorption and Physicomechanical Properties
}

\section{Utjecaj termo-mehaničke obrade moso- bambusa (Phyllostachys pubescens) na njegovu sorpciju i fizičko-mehanička svojstva}

\author{
Original scientific paper $\cdot$ Izvorni znanstveni rad \\ Received-prispjelo: 23. 10. 2018. \\ Accepted-prihvaćeno: 4. 7. 2019. \\ UDK: $630 * 812.222 ; 630 * 812.224 ; 630 * 812.421 ; 630 * 812.73$ \\ https://doi.org/10.5552/drvind.2019.1847
}

\begin{abstract}
The aim of this study was to examine some properties of heat-treated $\left(20{ }^{\circ} \mathrm{C}\right)$ and densified (treated) bamboo. Density ( $\rho$ ), equilibrium moisture content (EMC), sorption hysteresis (H), swelling (S), and Brinell hardness (HB) were examined and compared with untreated bamboo (Phyllostachys sp.) and common oak (Quercus robur $L$.). The density of heat-treated bamboo $\left(\rho=1170 \mathrm{~kg} / \mathrm{m}^{3}\right)$ was higher than that of untreated bamboo ( $\rho$ $\left.=850 \mathrm{~kg} / \mathrm{m}^{3}\right)$ and oak wood $\left(\rho=670 \mathrm{~kg} / \mathrm{m}^{3}\right)$. The sorption isotherms were parameterized with the GuggenheimAnderson-deBoer (GAB) model. Treated bamboo showed lower EMC than untreated bamboo and oak wood in the entire hygroscopic range. The swelling anisotropy index of treated bamboo was the lowest (1.09). The mean HB of treated bamboo $(H B=132 \mathrm{MPa})$ was significantly higher than that of oak and untreated bamboo.
\end{abstract}

Keywords: dynamic vapor sorption, equilibrium moisture content, sorption properties, Brinell hardness, GAB model, sorption hysteresis

SAŽETAK • Cilj ovog rada bio je istražiti neka svojstva toplinski obrađenoga $\left(20{ }^{\circ} \mathrm{C}\right)$ i ugušćenog (obrađenog) bambusa. Ispitivana je gustoća bambusovih uzoraka ( $\rho$ ), ravnotežni sadržaj vode u njima (EMC), histereza sorpcije (H), bubrenje (S) i tvrdoća prema Brinellu (HB), a dobivene su vrijednosti uspoređene s neobrađenim uzorcima

\footnotetext{
${ }^{1}$ Author is assistant professor at Poznan University of Life Science, Faculty of Wood Technology, Department of Wood Science, Poznań, Poland. ${ }^{2}$ Author is assistant professor at Poznan University of Life Science, Faculty of Wood Technology, Department of Engineering Mechanics and Thermal Techniques, Poznań, Poland. ${ }^{3}$ Author is assistant professor at Poznan University of Life Science, Faculty of Wood Technology, Institute of Wood Chemical Technology, Poznań, Poland.

' Autor je docent Sveučilišta prirodoslovnih znanosti u Poznanju, Fakultet drvne tehnologije, Zavod za znanost o drvu, Poznanj, Poljska. ${ }^{2} \mathrm{Au}-$ tor je docent Sveučilišta prirodoslovnih znanosti u Poznanju, Fakultet drvne tehnologije, Zavod za inženjersku mehaniku i toplinske tehnike, Poznanj, Poljska. ${ }^{3}$ Autor je docent Sveučilišta prirodoslovnih znanosti u Poznanju, Fakultet drvne tehnologije, Institut za kemijsku tehnologiju drva, Poznanj, Poljska.
} 
bambusa (Phyllostachys sp.) i drvom hrasta lužnjaka (Quercus robur L.). Pokazalo se da je gustoća toplinski obrađenog bambusa $\left(\rho=1170 \mathrm{~kg} / \mathrm{m}^{3}\right)$ veća od gustoće neobrađenih uzoraka bambusa $\left(\rho=850 \mathrm{~kg} / \mathrm{m}^{3}\right)$ i uzoraka hrastovine $\left(\rho=670 \mathrm{~kg} / \mathrm{m}^{3}\right)$. Izoterme sorpcije parametrirane su modelom Guggenheim-Anderson-deBoer $(G A B)$. Obrađeni su uzorci bambusa imali niži ravnotežni sadržaj vode od neobrađenih, kao i od uzoraka hrastovine, i to u cijelom rasponu higroskopnosti. Indeks bubrenja obrađenog bambusa bio je najniži $(1,09)$. Srednja vrijednost tvrdoće prema Brinellu obrađenog bambusa $(H B=132 \mathrm{MPa})$ bila je značajno veća od tvrdoće prema Brinellu hrastovine i neobrađenog bambusa.

Ključne riječi: dinamička sorpcija pare, ravnotežni sadržaj vode, sorpcijska svojstva, tvrdoća prema Brinellu, GAB model, histereza sorpcije

\section{INTRODUCTION} 1. UVOD

The suitability of a given type of wood for flooring is determined by high stability of dimensions, limited hygroscopicity, high density and hardness (Tsoumis, 1991). Among exotic species, those most often mentioned as suitable for flooring include: African mahogany (Khaya ivorensis A. Chev.), iroko (Milicia excels Welw.), merbau (Intsia bijuga Kuntze.), sucupira (Diplotropis purpura Sprague), jatoba (Hymenea courbaril Linn.). Wood of these species shows very good mechanical properties and high resistance to adverse effects of outside factors (e.g. biotic ones). Among European wood species often used as flooring material, oak (Quercus robur L.) is often mentioned, for both indoor and outdoor use. Oak wood shows a rather low fibre saturation point, close to $24 \%$, good mechanical properties and intermediate shrinkage values (Wagenführ, 2007). Increasing deficit of oak wood on the European market has prompted the interest in wood of different species and in modifications of wood of fast growing species. The latter group includes bamboo, as it is one of the fastest growing plants in the world and shows the ability to generate wooden stems. The great diversity of bamboo applications, evaluated as 5000 types, comprises the production of flooring materials (Lee et al., 2012) and construction boards (Sumardi and Suzuki, 2014). Among 1500 bamboo species (Khalil et al., 2012), moso bamboo (Phyllostachys pubescens) seems to be particularly attractive as it shows good physical and mechanical properties (Amada et al., 1997; Shao et $a l ., 2010$ ) and can be successfully grown in Europe because it tolerates low temperatures. Bamboo is hygroscopic, similarly as other lignocellulose materials, which affects the stability of its dimensions and its mechanical parameters. In order to reduce the effect of hygroscopicity on the above properties, bamboo is subjected to thermal treatment, which also changes its physical properties, e.g. may lead to a $50 \%$ increase in dimensional stability, and mechanical properties (Bekhta and Niemz, 2003; Esteves and Pereira, 2008). Densification is one of the first procedures used for the improvement of wood properties (Kollmann et al., 1975). Densification of fast-growing species, which leads to material of high density and good mechanical properties, is of particular importance (Morsing, 2000). Bamboo subjected to a combination of heat treatment and densification becomes an attrac- tive flooring material. The aim of the study is to determine the physical and mechanical properties of bamboo and oak wood and compare these properties with those of bamboo subjected to thermal treatment and densification.

\section{MATERIALS AND METHODS} 2. MATERIJALI I METODE

\subsection{Materials}

2.1. Materijali

The material studied was moso bamboo (untreated). It was not possible to obtain reference material of the same species, so the material of the genus Phyllostachys was used. Its properties were compared to those of moso bamboo (Phyllostachys pubescens) subjected to densification (up to the density of over $1000 \mathrm{~kg} / \mathrm{m}^{3}$ ) and patented heat-treatment process at $200{ }^{\circ} \mathrm{C}$ according to the MOSO technology. In Europe, bamboo is classified as an exotic species. The properties of untreated and treated bamboo were compared with those of the control material, which was heartwood of oak trees (Quercus robur L.).

\subsection{Methods}

2.2. Metode

\subsubsection{Chemical analysis}

2.2.1. Kemijska analiza

The samples were ground in a laboratory mill Fritsch type Pulverisette 15 (Fritsch GmbH, Germany). For chemical analyses, the $0.5-1.0 \mathrm{~mm}$ wood sawdust fraction was used. Substances soluble in organic solvent (96\% ethanol), in cold and hot water, in alkali $(1 \% \mathrm{NaOH})$, ash, cellulose, pentosans and lignin were analysed. The substances soluble in organic solvent, water and alkali were analysed according to TAPPI T $204 \mathrm{~cm}-07$ (2007), TAPPI T $207 \mathrm{~cm}$ 08 (2008) and TAPPI T 212 om-18 (2018) standards, respectively. Ash content was determined based on TAPPI T 211 om-07 standard (2007). The content of cellulose was determined using the Kürschner-Hoffer method. The content of pentosans was determined according to the procedure recommended by the Technical Association of Pulp and Paper Industry (TAPPI) T $223 \mathrm{~cm}-01$ standard (2001). The content of acidinsoluble lignin was estimated based on TAPPI T 222 om-06 standard (2006), using $72 \%$ sulphuric acid to hydrolyse and solubilise carbohydrates. All analyses were repeated three times for each examined sample batch. 


\subsubsection{Determination of wood density}

\subsubsection{Određivanje gustoće drva}

Physical properties and wood hardness were determined on wood samples $20(\mathrm{R}) \mathrm{mm} \times 20(\mathrm{~T}) \mathrm{mm} \times 30$ (L) $\mathrm{mm}$. For the untreated bamboo sample, the radial dimension (R) was the thickness of the stem wall, while for the treated bamboo the radial dimension was the thickness of the terrace board. The sample densities were determined according to the method recommended by ISO 13061-2:2014. The mass of each sample was measured on an analytical balance (Sartorius GmbH, Germany) ( $\pm 0.001 \mathrm{~g}$ accuracy). The dimensions were measured with digital calliper to the accuracy of $\pm 0.01 \mathrm{~mm}$.

\subsubsection{Sorption experiments}

2.2.3. Istraživanje sorpcije

Sorption experiments were made using a dynamic vapour sorption (DVS) apparatus (DVS Advantage 2 from Surface Measurement Systems, London, UK). The $E M C$ values were recorded for 10 levels of air humidity $(R H)$ in the range from 0 to $95 \%$ in the adsorption/desorption modes at $20^{\circ} \mathrm{C}$. The appropriate air $R H$ levels were achieved by mixing dry and saturated air streams. The samples were stored in a desiccator over $\mathrm{P}_{2} \mathrm{O}_{5}$ for two weeks leading to an $E M C$ close to 0 . The average mass of each sample was ca. $(7 \pm 0.5) \mathrm{mg}$.

The pre-dried samples were always equilibrated in a DVS apparatus in dry nitrogen. Then, the air $R H$ was stepwise increased. It was assumed that the hygroscopic equilibrium was obtained at a given air $R H$ value when the mass change was less than $0.001 \% / \mathrm{min}$ for at least $60 \mathrm{~min}$. The procedure was repeated for each $R H$ step for the adsorption/desorption modes and the $E M C$ values were calculated.

\subsubsection{Sorption isotherm modelling}

\subsubsection{Modeliranje izoterme sorpcije}

The adsorption/desorption isotherms were calculated according to the Guggenheim, Anderson, and De Boer (GAB) equation (Basu et al., 2006):

$$
E M C=M_{\mathrm{m}} \frac{100 \cdot K \cdot C \cdot R H}{(100-K \cdot R H) \cdot(100-K \cdot R H+C \cdot K \cdot R H)}(1)
$$

where $E M C(\%)$ - equilibrium moisture content, $R H$ $(\%)$ - air relative humidity, $M_{m}(\%)$ - monolayer capacity, $C$ - equilibrium constant related to the monolayer sorption (also known as the Guggenheim constant), $K$ - equilibrium constant related to the multilayer sorption. The GAB model is an extension of the BrunauerEmmett-Teller (BET) model. In contrast to the BET equation, it postulates an enthalpy decrease of polymolecular water. The mathematical analysis of the GAB model shows that it can be simplified to the BET equation when $K=1$ (e.g. Furmaniak et al., 2007).

The estimators of the sorption hysteresis, i.e. the maximum difference of $E M C$ for desorption and adsorption $(\triangle E M C)$, the hysteresis loop $(H)$ and its relative change $(\delta H)$, proposed by Majka et al. (2016) were used.

\subsubsection{Wood swelling}

2.2.5. Bubrenje drva

Swelling $(S)$ was measured for twin samples of the size $20 \mathrm{~mm} \times 20 \mathrm{~mm} \times 30 \mathrm{~mm}$ in radial (R), tangen-

tial (T) and longitudinal (L) anatomical direction, respectively. The dimensions of the samples were measured by a digital calliper to the accuracy of $0.01 \mathrm{~mm}$. Mass of the samples was determined to the accuracy of $0.001 \mathrm{~g}$. All samples were placed in desiccators above an oversaturated salt solution ensuring the air $\mathrm{RH}$ equal to $25\left(\mathrm{CH}_{3} \mathrm{COOK}\right), 45\left(\mathrm{~K}_{2} \mathrm{CO}_{3} \times 2 \mathrm{H}_{2} \mathrm{O}\right), 85(\mathrm{KCl})$ and $98 \%\left(\mathrm{~K}_{2} \mathrm{So}_{4}\right)$ at the temperature of $25{ }^{\circ} \mathrm{C}$. The samples were conditioned in such environment until the stabilisation of their mass or until the moment when in three consecutive weightings, made after an interval of 12 hours, the weight difference was not greater than 0.01 g. The swelling $(S)$ was measured after the sample reached the hygroscopic equilibrium, the tangential (T) and radial $(\mathrm{R})$ anatomical directions according to the following equation:

$$
S=\frac{l-l_{0}}{l_{0}} \cdot 100
$$

where $l(\mathrm{~mm})$ - dimension of a sample, i.e. for the equilibrium moisture content, $l_{0}(\mathrm{~mm})$ - dimension of a sample in oven-dry state (initial dimension).

\subsubsection{Brinell hardness}

\subsubsection{Tvrdoća prema Brinellu}

The wood hardness in transversal direction was measured by the Brinell method, according to PN-EN 1534 norm. The measurements were made using a steel ball of $10 \mathrm{~mm}$ diameter and a maximum load of $1 \mathrm{kN}$. It took 15 seconds to reach the maximum load; the load was maintained for 30 seconds, then within 15 seconds the load gradually decreased to zero. Brinell hardness was calculated as follows:

$$
H_{B}=\frac{2 F}{\pi D\left(D-\sqrt{D^{2}-d^{2}}\right)}
$$

where $H B$ is the Brinell hardness $(\mathrm{MPa}), F$ is the nominal force $(\mathrm{N}), D$ is the diameter of the steel ball (10 $\mathrm{mm})$, and $d$ is the mean diameter of the residual indentation $(\mathrm{mm})$.

\subsubsection{Statistical analysis \\ 2.2.7. Statistička analiza}

The experimental data were analysed using the Dell $^{\mathrm{TM}}$ Statistica ${ }^{\mathrm{TM}} 13.1$ software with the analysis of variance (ANOVA). Significant differences between mean values of the parameters describing the properties of oak, and untreated and treated bamboo samples were determined using Tukey's HSD test. The comparison tests were performed at a 0.05 significance level. Identical superscripts e.g. a, b, c denote no significant difference between mean values of the investigated properties.

\section{RESULTS AND DISCUSSION} 3. REZULTATI I RASPRAVA

\subsection{Chemical analysis}

3.1. Kemijska analiza

Table 1 presents the results of chemical composition determined for the samples of untreated and treated bamboo and oak wood. The untreated bamboo contained lower amounts of substances soluble in ethanol (resins, waxes and fats) and soluble in water (monosac- 
Table 1 Chemical composition of bamboo and oak wood (\%)

Tablica 1. Kemijski sastav bambusa i hrastovine (\%)

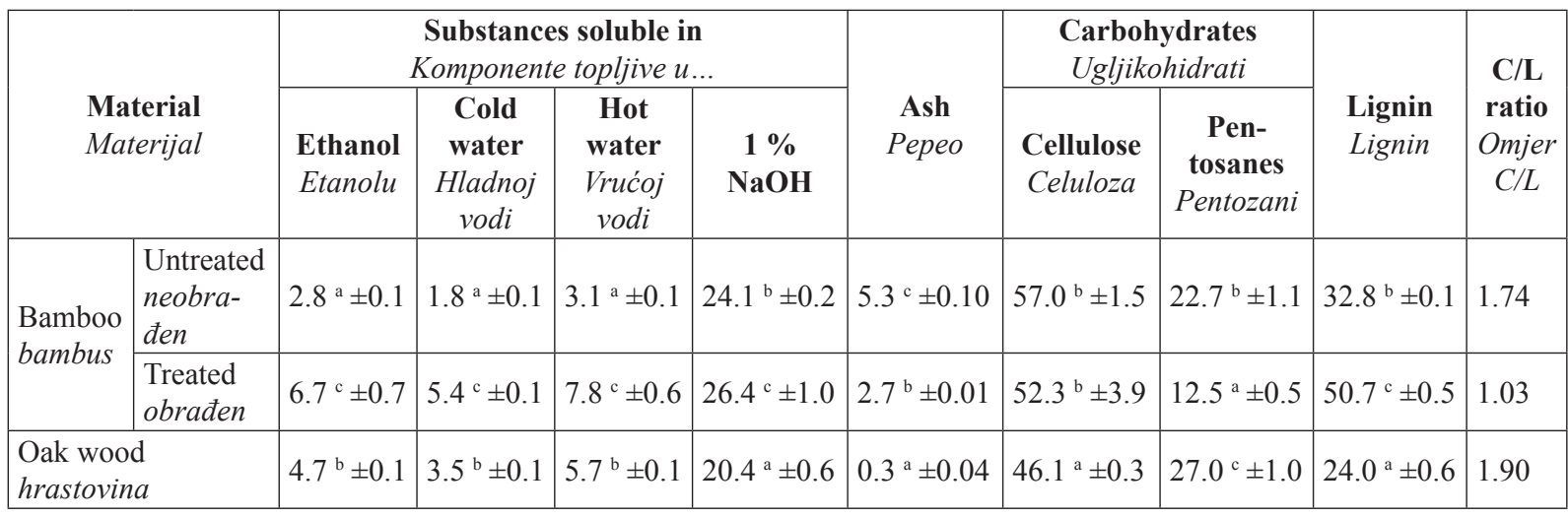

Mean values $(n=3) \pm$ standard deviations / srednje vrijednosti $(n=3) \pm$ standardne devijacije

charides, tannins, dyes and starch) than oak wood and treated bamboo. Statistically significant differences in chemical composition between the untreated and treated bamboo illustrate the impact of heat treatment. The content of substances soluble in $1 \% \mathrm{NaOH}$ (hemicelluloses and products of lignin and cellulose degradation, phenolic compounds) in the untreated and treated bamboo is higher than in oak wood, which agrees with literature data for the species (Tamolang et al., 1980). The content of substances soluble in $1 \% \mathrm{NaOH}$ higher in treated than in untreated bamboo can be related to the degradation of pentosanes upon bamboo treatment. In general, treated bamboo contains more non-structural components than untreated bamboo, which is probably the result of their thermal decomposition. Untreated and treated bamboo show higher contents of cellulose and lignin than oak heartwood which, however, contains more pentosanes. The differences in the content of cellulose between untreated and treated bamboo are not statistically significant, which means that this component is resistant to heat treatment. However, the differences in the contents of pentosanes and lignin between untreated and treated bamboo are statistically significant. The heat treatment caused degradation of about $45 \%$ pentosanes sensitive to elevated temperatures (Fengel and Wegener, 1989). The increase in the content of lignin as a result of heat treatment is probably related to the decrease in the content of pentosanes. Moreover, the heat-treated bamboo is characterized by a low C/L index (1.03), which means that the contents of cellulose and lignin in this sample are very close. A low $\mathrm{C} / \mathrm{L}$ value and high content of non-structural substances imply that the physicomechanical properties of heat-treated bamboo are probably much different from those of untreated bamboo and oak.

\subsection{Wood density}

The results of density measurements for the samples studied are given in Table 2 .

The results revealed statistically significant differences between the mean values of all samples. The smallest variation in density was found for oak wood. The density of untreated bamboo was by $27 \%$ higher
Table 2 Densities of wood samples studied $\left(\mathrm{kg} / \mathrm{m}^{3}\right)$ Tablica 2. Gustoća istraživanih uzoraka drva $\left(\mathrm{kg} / \mathrm{m}^{3}\right)$

\begin{tabular}{|l|l|l|l|l|}
\hline \multicolumn{2}{|l|}{ Material / Materijal } & Mean \pm SD & Min & Max \\
\hline $\begin{array}{l}\text { Bamboo } \\
\text { bambus }\end{array}$ & $\begin{array}{l}\text { Untreated } \\
\text { neobrađen }\end{array}$ & $852^{\mathrm{b}} \pm 54$ & 781 & 940 \\
\cline { 2 - 6 } & $\begin{array}{l}\text { Treated } \\
\text { obrađen }\end{array}$ & $1171^{\mathrm{c}} \pm 62$ & 1076 & 1260 \\
\hline \multicolumn{2}{|l|}{ Oak wood / hrastovina } & $672^{\mathrm{a}} \pm 7$ & 656 & 683 \\
\hline
\end{tabular}

Mean values $(n=10) \pm$ standard deviations / srednje vrijednosti $(n=10) \pm$ standardne devijacije

than that of oak. The average density of bamboo can vary from 550 to $1010 \mathrm{~kg} / \mathrm{m}^{3}$ depending on the site of sample cutting (Razak et al., 2007). The heat treatment and densification of bamboo resulted in the density increase by $38 \%$ with respect to that of untreated bamboo.

\subsection{Adsorption and desorption}

\subsection{Adsorpcija i desorpcija}

The obtained sorption isotherms are presented in Figure 1. Each plot consists of two sets of isotherm loops, i.e. oak wood and untreated or treated bamboo. The isotherms were constructed by fitting the GAB model to each set of experimental data, the measured $E M C$ values are also depicted in the plots.

A comparison of the sorption isotherms, shown in Figure 1a, reveals small differences in the equilibrium moisture content between oak and untreated bamboo. For the $R H$ greater than $40 \%$, the equilibrium moisture content of untreated bamboo was lower than that of oak in both sorption phases. The treated bamboo showed much reduced EMC in the entire range of relative air humidity studied and much smaller area of the hysteresis loop than that of oak wood, Figure 1b. The decrease in $E M C$ is interpreted as a consequence of about $10.2 \%$ reduced contribution of pentosanes in treated bamboo relative to that in the untreated sample (see Table 1). It is a well-known result of thermal decomposition of hemicelluloses, i.e. the most hygroscopic component of wood cell walls. The lowest $E M C$ for treated bamboo is also a result of high content of extractives as shown in Table 1. The influence of extractives on the sorption phenomenon has been previously reported by Simón et al. (2015), and it has been 


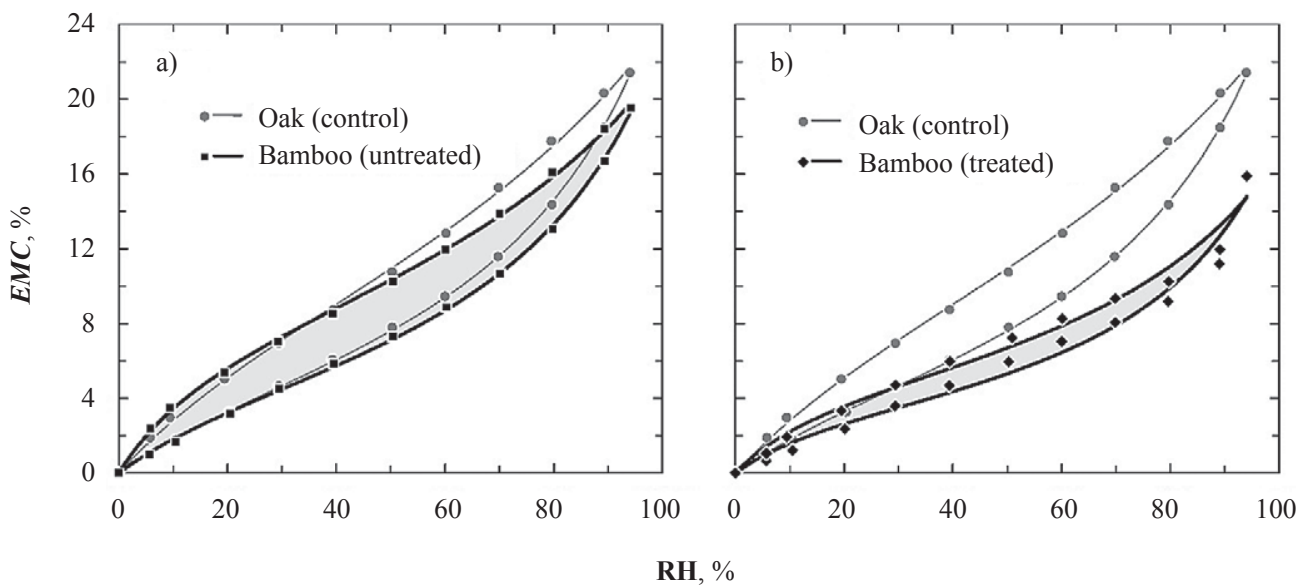

Figure 1 Sorption isotherms of bamboo at temperature of $25^{\circ} \mathrm{C}$ compared to those of oak wood. Sorption isotherms estimated with the GAB model, dots represent experimental data, grey area is the sorption hysteresis loop

Slika 1. Izoterme sorpcije bambusa pri temperaturi $25^{\circ} \mathrm{C}$ u usporedbi s hrastovinom; izoterme sorpcije procijenjene su GAB modelom; točke predočuju eksperimentalne podatke, a siva je zona histereza sorpcije

pointed out that high concentration of extractives causes a decrease in EMC. Spalt (1958) has observed that wood with a high content of extractives reveals low $E M C$, especially when air $R H$ is above $50 \%$.

The GAB sorption model was separately fitted to the data obtained for bamboo and oak wood whose adsorption and desorption isotherms were determined. The Statistica ${ }^{\mathrm{TM}} 13.1$ software, with the implemented Levenberg-Marquardt iterative algorithm, was applied to estimate the coefficients of the models of the sorption isotherms. The results of fitting are presented in Table 3.

The values of $M_{m}$ coefficient of the GAB model of untreated bamboo were slightly lower than those of oak wood, while for thermally treated and densified bamboo this parameter was much lower. This can be explained by the fact that the treatment reduced the accessibility of the primary sorption sites in the treated bamboo.

The values of $C$ coefficient were higher than 2 for all estimated isotherms, which is the necessary condition for classifying the isotherms as type II. An additional condition for recognizing sorption isotherms as type II was proposed by Lewicki (1997). The conjunction of the relations $5.57 £ C<\infty$ and $0.24<K £ 1$ was not satisfied (Table 3 ). Therefore, not all isotherms could be classified as (fully sigmoidal) type II. This coefficient represents the total heat of sorption of the monolayer water and its values have to be positive (Maskan and Göğüş, 1997). The $C$ values were significantly higher than $K$, which indicates much higher heat of sorption of the monolayer as compared to the multilayer (de Oliveira et al., 2017). It was found that the thermal modification and densification of bamboo caused an increase in $C$ coefficient for adsorption, which can be interpreted as a result of stronger binding of the water monolayer to the primary sorption sites. In the process of desorption, the $C$ coefficient value was higher for untreated bamboo than for oak wood, which means that the removal of the water monolayer from the material structure required more heat. Almost identical values of $C$ coefficient in the assumed model of sorption for the untreated and treated bamboo indicate that thermal treatment and densification of bamboo do not lead to an increase in the heat needed for the removal of water from the material structure.

The $K$ coefficient is related to the water multilayer. The coefficient was significantly lower than 1 for all the studied sorption isotherms (Table 3), which complies with its physical meaning (Timmermann, 2003). A decrease in the $K$ coefficient was interpreted by Timmermann et al. (2001) as corresponding to the less structured state of the water multilayer. The highest values of $K$ were recorded for treated bamboo, which implied that in this wood sample the water multilayer was characterized by a higher degree of ordering than in untreated bamboo and oak wood.

The obtained descriptors of sorption hysteresis are presented in Figure 2 and Table 4. The most remarkable alteration of the hysteresis was found for thermal modified and densified bamboo. The hysteresis loop $(H)$ was significantly reduced, i.e. it was as small

Table 3 Estimated coefficients of the sorption GAB model for bamboo and oak wood Tablica 3. Procijenjeni koeficijenti sorpcijskoga GAB modela za bambus i hrastovinu

\begin{tabular}{|l|l|l|c|c|c|c|c|}
\hline \multicolumn{2}{|c|}{ Material / Materijal } & $\begin{array}{l}\text { Sorption phase } \\
\text { Faza sorpcije }\end{array}$ & $\boldsymbol{M}_{\boldsymbol{m}} \mathbf{( \% )}$ & $\boldsymbol{K}$ & $\boldsymbol{C}$ & $\boldsymbol{R}^{2}$ & $\boldsymbol{S E}$ \\
\hline \multirow{3}{*}{$\begin{array}{l}\text { Bamboo } \\
\text { bambus }\end{array}$} & $\begin{array}{l}\text { Untreated } \\
\text { neobrađen }\end{array}$ & Adsorption & 5.86 & 0.7646 & 4.8451 & 0.9994 & 0.0018 \\
\cline { 2 - 9 } & $\begin{array}{l}\text { Treated } \\
\text { obrađen }\end{array}$ & Adsorption & 9.10 & 0.6131 & 8.4089 & 0.9993 & 0.0019 \\
\cline { 2 - 9 } & Desorption & 3.90 & 0.7969 & 6.9023 & 0.9800 & 0.0074 \\
\hline \multirow{2}{*}{ Oak wood / hrastovina } & Adsorption & 6.28 & 0.7044 & 8.4476 & 0.9829 & 0.0069 \\
\cline { 2 - 8 } & Desorption & 12.11 & 0.7663 & 4.0795 & 0.9998 & 0.0010 \\
\hline
\end{tabular}


Table 4 Sorption hysteresis loop $(H)$, hysteresis relative change $(\delta H)$, maximum difference in equilibrium moisture content for desorption and adsorption $(\triangle E M C)$ and corresponding air relative humidity $(R H)$ indices for bamboo and oak wood Tablica 4. Histereza sorpcije $(H)$, relativna promjena histereze $(\delta H)$, najveća razlika ravnotežnog sadržaja vode za desorpciju i adsorpciju $(\triangle E M C)$ i odgovarajuća relativna vlažnost zraka $(R H)$ za bambus i hrastovinu

\begin{tabular}{|c|c|c|c|c|c|}
\hline \multirow{2}{*}{\multicolumn{2}{|c|}{ Material / Materijal }} & \multicolumn{4}{|c|}{ Hysteresis descriptors / Deskriptori histereze } \\
\hline & & $H$ (arb. units) & $\delta H, \%$ & $\triangle E M C, \%$ & $R H, \%$ \\
\hline \multirow{2}{*}{$\begin{array}{l}\text { Bamboo } \\
\text { bambus }\end{array}$} & Untreated / neobrađen & 233.7 & +2.2 & 3.26 & 57 \\
\hline & Treated / obrađen & 97.9 & -57.2 & 1.42 & 61 \\
\hline \multicolumn{2}{|c|}{ Oak wood / hrastovina } & 228.6 & - & 3.54 & 63 \\
\hline
\end{tabular}

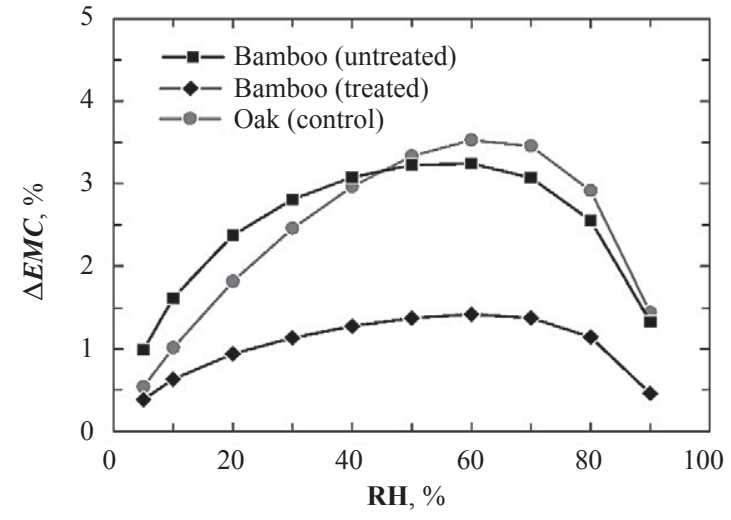

Figure 2 Sorption hysteresis of untreated and treated bamboo and oak wood

Slika 2. Histereza sorpcije neobrađenih i obrađenih uzoraka bambusa i hrastovine

as 97.9 and it corresponded to the plot in Figure 2. The applied treatment of bamboo resulted in a significant reduction of the sorption hysteresis loop to the level of ca. $57 \%$ as compared with that of the untreated material (Table 4). The reduction in the area of the hysteresis loop indicates a decrease in the free energy of the sorption process and a consequent improvement in dimensional stability (Esteban et al. 2008). The untreated bamboo revealed only slightly lower sorption hysteresis than oak wood i.e. 233.7. This tendency was also supported by other estimators presented in Table 4 and the course of $\triangle E M C$ for desorption and adsorption as a function of air $R H$ (Figure 2). Moreover, for the untreated bamboo, the maximum difference in $E M C$ be- tween the desorption and adsorption phases was by ca. 2.5 times smaller than for oak wood.

\subsection{Swelling \\ 3.4. Bubrenje}

Figure 3 illustrates the swelling of the sample studied in the tangential and radial directions. According to Wagenführ (2007), oak wood is characterised by intermediate values of shrinkage, while for untreated bamboo the corresponding values are low. The oak wood swelling reached about 4 and $7 \%$ in the radial and tangential anatomical directions, respectively, while the corresponding values for untreated bamboo were about 5 and $6 \%$, respectively. As follows from the comparison of swelling recorded for treated and untreated bamboo, Figure 3, the thermo-mechanical modification of bamboo also led to a reduction of its moisture deformation. Thermo-mechanically treated bamboo showed much smaller degree of swelling in the whole range of hygroscopicity than untreated bamboo and oak wood. The wood swelling of treated bamboo was about $3 \%$ in both radial and tangential directions. This result means that it is reasonable to expect that the thermo-mechanical treatment of bamboo will improve the dimensional stability of products made of this wood. The reduced swelling of thermally treated bamboo relative to that of untreated wood is a result of decreased hygroscopicity of the former.

Thermo-mechanical treatment of moso bamboo also resulted in a decrease in the swelling anisotropy index. Its lowest value of 1.09 was obtained for treated bamboo, while the value obtained for oak wood was much higher, 1.58 .
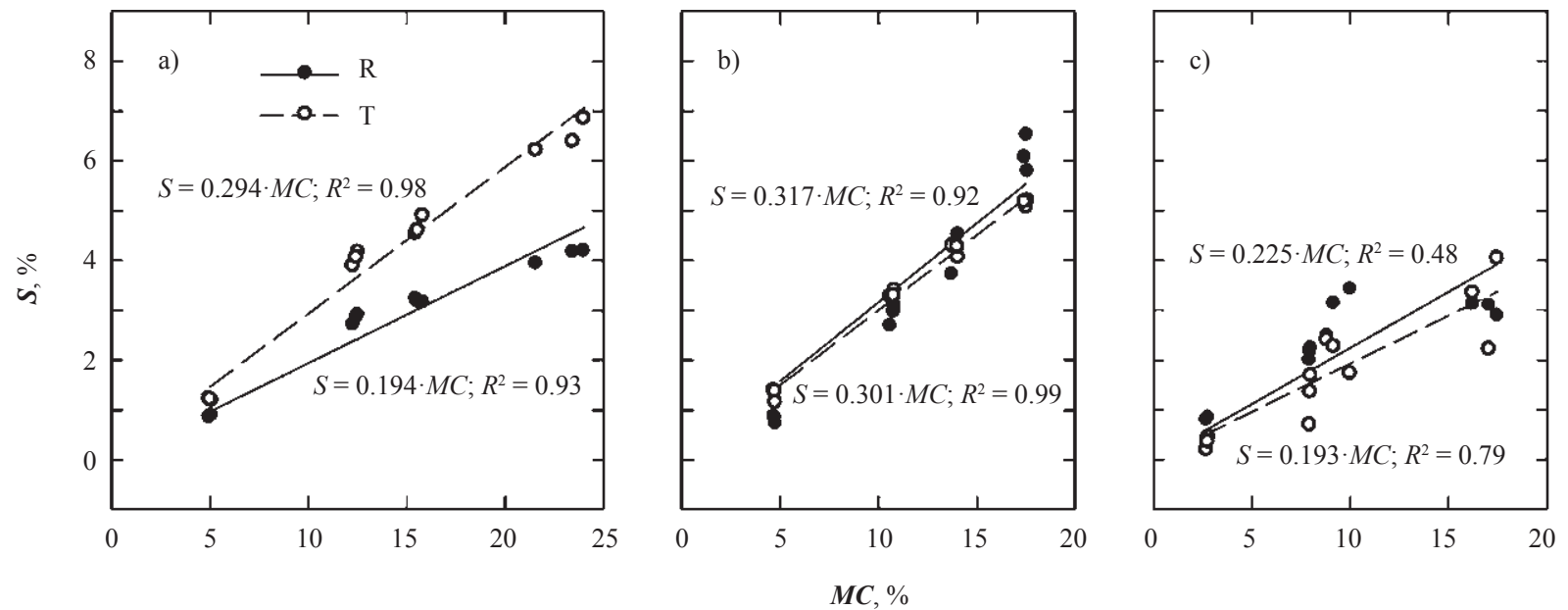

Figure 3 Comparison of swelling of (a) oak wood, (b) untreated bamboo and (c) treated bamboo in radial (R) and tangential (T) anatomical direction

Slika 3. Usporedba bubrenja (a) hrastovine, (b) neobrađenog bambusa i (c) obrađenog bambusa u radijalnome (R) i tangentnom (T) smjeru 


\subsection{Brinell hardness}

\subsection{Tvrdoća prema Brinellu}

Table 5 presents the results of $H B$ determination for all samples studied. Oak wood is considered to be of high hardness, and the mean value of hardness for oak wood in the transversal plane was $H B_{\perp}=56 \mathrm{MPa}$. The differences between the mean $\mathrm{HB}$ values determined for oak wood and untreated bamboo are statistically insignificant. The hardness of both treated and untreated bamboo was higher than that of oak wood; however the hardness of treated bamboo was about 3 times higher. The process of densification resulted in a significant increase in $H B$. Thanks to the applied modification (thermal treatment and densification), moso bamboo has become an excellent material for high quality flooring. Its $H B$ was higher than that of merbau $\left(H B_{\perp}=89 \mathrm{MPa}\right)$, courbaril $\left(H B_{\perp}=56 \mathrm{MPa}\right)$ or ipe $\left(H B_{\perp}=49 \mathrm{MPa}\right)$ (Wagenführ, 2007).

Table 5 Bamboo and oak wood $(H B)$ in radial $\mathrm{R}$ and tangential $\mathrm{T}$ anatomical directions

Tablica 5. Tvrdoća prema Brinellu $(H B)$ bambusa i hrastovine $\mathrm{u}$ radijalnome $(\mathrm{R}) \mathrm{i}$ tangentnom $(\mathrm{T})$ smjeru

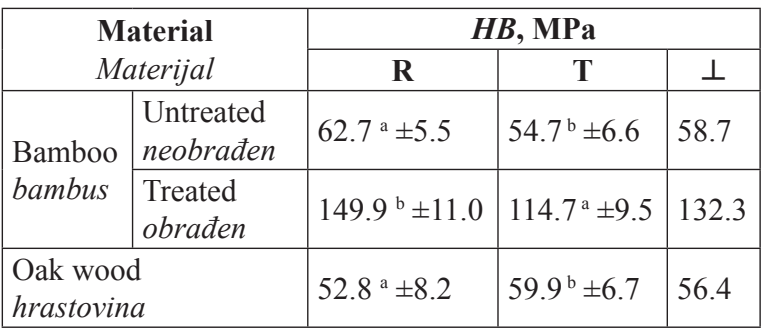

\section{CONCLUSIONS}

\section{ZAKLJUČAK}

According to the results presented and discussed above, untreated bamboo can satisfactorily replace oak wood for flooring production as the properties of these two types of wood are similar. The applied modification of moso bamboo, comprising heat treatment and densification, has been proved to considerably improve the properties of this wood qualifying it as the flooring material. The thermomechanical treatment of bamboo resulted in increasing its density from about 800 to over $1150 \mathrm{~kg} / \mathrm{m}^{3}$, in increasing the degree of the water multilayer and in increasing the amount of heat needed for the removal of water from moso bamboo structure. It also brought about a significant decrease in hygroscopicity, decrease in the hysteresis of sorption and restricted the water access to primary sorption sites in modified moso bamboo, which enhanced its dimensional stability. Another beneficial effect of the treatment applied is almost double reduction of swelling in the direction perpendicular to the fibres. Also, the Brinell hardness of modified bamboo was almost twice greater than that of untreated bamboo and oak wood. In view of the above, it can be concluded that treated bamboo is a highly suitable material for the applications in which it is exposed to the adverse effects of external factors and elements.

\section{REFERENCES}

\section{LITERATURA}

1. Amada, S.; Ichikawa, Y.; Munekata, T.; Nagase, Y.; Shimizu, H., 1997: Fiber texture and mechanical graded structure of bamboo. Composites Part B: Engineering, 28B: $1-20$.

https://doi.org/10.1016/S1359-8368(96)00020-0.

2. Basu, S.; Shivhare, U. S.; Mujumdar, A. S., 2006: Models for sorption isotherms for food: A review. Drying Technology, 24: 917-930. https://doi.org/10.1080/07373930600775979.

3. Bekhta, P.; Niemz, P., 2003: Effect of high temperature on the change in color, dimensional stability and mechanical properties of spruce wood. Holzforschung, 57: 539-546. https://doi.org/10.1515/HF.2003.080.

4. Esteban, L. G.; de Palacios, P.; Fernandez, F. G.; Guindeo, A.; Conde, M.; Baonza, V., 2008: Sorption and thermodynamic properties of juvenile Pinus sylvestris L. wood after 103 years of submersion. Holzforschung, 62: 745751. https://doi.org/10.1515/HF.2008.106.

5. Esteves, B.; Pereira, H., 2008: Quality assessment of heat-treated wood by NIR spectroscopy. Holz als Rohund Werkstoff, 66: 323-332.

https://doi.org/10.1007/s00107-008-0262-4.

6. Fengel, D.; Wegener, G., 1989: Wood-Chemistry, Ultrastructure, Reactions, $2^{\text {nd }}$ ed. Walter de Gruyter, Berlin. https://doi.org/10.1002/pol.1985.130231112.

7. Furmaniak, S.; Terzyk, A. P.; Gauden, P. A., 2007: The general mechanism of water sorption on foodstuffs - Importance of the multi temperature fitting of data and the hierarchy of models. Journal of Food Engineering, 82: 528-535.https://doi.org/10.1016/j.jfoodeng.2007.03.012.

8. Khalil, H. P. S. A.; Bhat, I. U. H.; Jawaid, M.; Zaidon, A.; Hermawan, D.; Hadi, Y. S.; 2012: Bamboo fibre reinforced biocomposites: A review. Materials \& Design, 42: 353-368. https://doi.org/10.1016/j.matdes.2012.06.015.

9. Kollmann, F. P.; Kuenzi E. W.; Stamm A. J., 1975: Principles of Wood Science and Technology, Vol. II: Wood Based Materials. Springer-Verlag, New York, Heidelberg, Berlin: 139-149. https://doi.org/ 10.1007/978-3-642-87931-9.

10. Kürschner, K.; Hoffer, A., 1929: Ein neues verfahren zur bestimmung der cellulose in holzern und. Zellstoffen Tech Chem Pap Zellst. 26: 125-129.

11. Lee, C. H.; Chung, M. J.; Lin, C. H.; Yang, T. H., 2012: Effects of layered structure on the physical and mechanical properties of laminated moso bamboo (Phyllosachys edulis) flooring. Construction and Building Materials, 28: 31-35. https://doi.org/10.1016/j.conbuildmat.2011.08.038.

12. Lewicki, P. P., 1997: The applicability of the GAB model to food water sorption isotherms. International Journal of Food Science \& Technology, 32: 553-557. https://doi.org/10.1111/j.1365-2621.1997.tb02131.x.

13. Majka, J.; Czajkowski Ł.; Olek, W., 2016: Effects of cyclic changes in relative humidity on the sorption hysteresis of thermally modified spruce wood. BioResources, 11: 5265-5275. https://doi.org/10.15376/biores.11.2.5265-5275.

14. Maskan, M.; Göğüş, F., 1997: The fitting of various models to water sorption isotherms of pistachio nut paste. Journal of Food Engineering, 33(3-4): 227-237. https://doi.org/10.1016/S0260-8774(97)00061-7.

15. Morsing, N., 2000: Densification of wood - The influence of hygrothermal treatment on compression of beech perpendicular to the grain. Department of structural engi- 
neering and materials technical university of Denmark, Series R, 79: $138 \mathrm{pp}$.

16. de Oliveira, G. H. H.; Corrêa, P. C.; de Oliveira, A. P. L. R.; Devilla, I. A., 2017: Application of GAB model for water desorption isotherms and thermodynamic analysis of sugar beet seeds. Journal of Food Process Engineering, 40: e12278. https://doi.org/10.1111/jfpe.12278.

17. Razak, W.; Janshah, M.; Hashim, W. S. S. B., 2007: Morphological and anatomical characteristics ofmanaged natural bamboo stands Gigantochloa scortechinii. Journal of Bamboo and Rattan, 6 (2)

18. Shao, Z. P.; Fang, C. H.; Huang, S. X.; Tian, G. L., 2010: Tensile properties of Moso bamboo (Phyllostachys pubescens) and its components with respect to its fiber-reinforced composite structure. Wood Science and Technology, 44 (4): 655-666. https://doi.org/10.1007/s00226-009-0290-1.

19. Simón, C.; Esteban, L. G.; Palacios, P.; Fernández, F. G., 2015: Thermodynamic analysis of water vapour sorption behaviour of juvenile and mature wood Abies alba Mill. Journal of Material Science, 50: 7282-7292. https://doi.org/10.1007/s10853-015-9283-7.

20. Spalt, H. A., 1958: The fundamentals of water vapor sorption by wood. Forest Products Journal, 8 (10): 288 295.

21. Sumardi, I.; Suzuki, S., 2014: Dimensional stability and mechanical properties of strandboard made from bamboo. BioResources, 9 (1): 1159-1167. https://doi.org/10.15376/biores.9.1.1159-1167.

22. Tamolang, F. N.; Lopez, A. R.; Semara, J. A.; Casin, R. F., Espiloy, Z. B., 1980: Properties and utilization of Philippine erect bamboos. Forpride digest, Laguna, v. 99, n. 34, p. 31-41, 1980.

23. Timmermann, E. O.; Chirife, J.; Iglesias, H. A., 2001: Water sorption isotherms of foods and foodstuffs: BET or
GAB parameters. Journal of Food Engineering, 48 (1): 19-31. https://doi.org/10.1016/S0260-8774(00)00139-4.

24. Timmermann, E. O., 2003: Multilayer sorption parameters: BET or GAB values. Colloid. Surface A, 220 (1-3): 235260. https://doi.org/10.1016/S0927-7757(03)00059-1.

25. Tsoumis, G., 1991: Science and technology of wood: structure, properties, utilization. New York: Chapman \& Hall, 1991, 494 p. https://doi.org/10.1163/22941932-90001279.

26. Wagenführ, R., 2007: Holzatlas. Fachbuchverlage, Lipsk. https://doi.org/10.1163/22941932-90001585.

27. *** PN-EN 1534: 2011 Wood flooring - determination of resistance to indentation - test method.

28. *** ISO 13061-2: 2014 Physical and mechanical properties of wood - Test methods for small clear wood specimens, part 2: Determination of density for physical and mechanical tests.

29. *** TAPPI, 1996-7 Standards, Technical Association of Pulp and Paper Industry, 15 Technology Parkway South, Norcross, GA 30092, USA, T204, T207, T211 and T222.

\section{Corresponding address:}

PRZEMYSŁAW MANIA, Ph.D.

Poznan University of Life Sciences

Faculty of Wood Technology

Department of Wood Science

Wojska Polskiego Street 38/42

60-637 Poznan, POLAND

e-mail: przemyslaw.mania@up.poznan.pl 